\title{
Sabellaria alveolata versus Sabellaria spinulosa Reefs along the Italian Coasts: A New Methodological Proposal to Compare Different Growth Models
}

\author{
Stefania Nunzia Lisco ${ }^{1, *}$, Cataldo Pierri ${ }^{2}$ DD, Tamara Lazic ${ }^{2}$, Andrea Bonifazi ${ }^{3}$, Maria Flavia Gravina ${ }^{3}$ (D), \\ Adriana Giangrande ${ }^{4}(\mathbb{D})$, Pasquale Acquafredda ${ }^{1}$ and Massimo Moretti $^{1}$ (D) \\ 1 Dipartimento di Scienze della Terra e Geoambientali, Università degli Studi di Bari, 70121 Bari, Italy; \\ pasquale.acquafredda@uniba.it (P.A.); massimo.moretti@uniba.it (M.M.) \\ 2 Dipartimento di Biologia, Università degli Studi di Bari, 70121 Bari, Italy; cataldo.pierri@uniba.it (C.P.); \\ tamara.lazic@uniba.it (T.L.) \\ 3 Dipartimento di Biologia, Roma Tor Vergata, 00133 Roma, Italy; bonifazi.andrea@virgilio.it (A.B.); \\ maria.flavia.gravina@uniroma2.it (M.F.G.) \\ 4 Dipartimento di Biologia, University of Salento, 73100 Lecce, Italy; adriana.giangrande@unisalento.it \\ * Correspondence: stefania.lisco@uniba.it
}

Citation: Lisco, S.N.; Pierri, C.; Lazic, T.; Bonifazi, A.; Gravina, M.F.; Giangrande, A.; Acquafredda, P.; Moretti, M. Sabellaria alveolata versus Sabellaria spinulosa Reefs along the Italian Coasts: A New Methodological Proposal to Compare Different Growth Models. Geosciences 2021, 11, 426. https://doi.org/10.3390/ geosciences 11100426

Academic Editors: Rossana Sanfilippo and Jesus Martinez-Frias

Received: 29 July 2021

Accepted: 11 October 2021

Published: 15 October 2021

Publisher's Note: MDPI stays neutral with regard to jurisdictional claims in published maps and institutional affiliations.

Copyright: (C) 2021 by the authors. Licensee MDPI, Basel, Switzerland. This article is an open access article distributed under the terms and conditions of the Creative Commons Attribution (CC BY) license (https:/ / creativecommons.org/licenses/by/ $4.0 /)$.

\begin{abstract}
Sabellaria species are among the most important frame-builders in temperate, shallow marine areas. These polychaetes are suspension feeders able to build bioconstructions using sand and shell fragments cemented with a sticky mucous. Such feature makes these invertebrates "unusual bioconstructors", as they do not produce calcium carbonate. Sabellaridae reefs are widespread in the Mediterranean and along the Atlantic coast of Europe, but their sedimentological aspects are still poorly known. Over short time intervals, these bioconstructions can rapidly alternate between phases of growth, stasis and destruction during different seasons. In this paper, we compare reefs of two Sabellaria species (S. alveolata-Ostia, Roma and Tyrrhenian Sea; S. spinulosa-Torre Mileto, Foggia and Adriatic Sea) found at two different sites along the Italian coast. We describe the morphology of worm tubes at the macro- and microscale. Similarities and differences are discussed based on eco-biological features and physical environmental conditions. This work shows a measurement and observation scheme for this type of bioconstructions that has been verified at both the macroand microscale and which was shown to be useful for defining evolutionary trends of sabellarian bioconstructions. The monitoring parameters were identified and verified over a long period.
\end{abstract}

Keywords: sabellarian bioconstructions; worm reef; sedimentology; sandy beaches

\section{Introduction}

Worm reefs are stable bioconstructions that are built by marine gregarious polychaetes able to form colonies very high densities at different depths [1,2]. Among frame-builder polychaetes, sabellariids form bioconstructions formed by adjacent and subparallel tubes, which are joined together with cement, sand grains and shells (whole or in fragments) using a glue secreted by the polychaetes [3-5]. As such, these bioconstructions have a crucial role in preventing coastal erosion by stabilizing the sediments involved [6]. The importance of these bioconstructions, although sometimes not long-lasting, is also linked to the high biodiversity of the associated fauna that contributes to defining a pattern similar to a community of hard, rather than soft, substrates [7].

Sabelliarian reefs can be found along the coasts of all oceans, although, according to the literature, they seem to be concentrated in temperate areas. Sabellaria reefs develop between 0 and $20 \mathrm{~m}$ of depth in intertidal or subtidal zones, depending on the species [8-15]. Sabellaria alveolata (Linnaeus 1767) and Sabellaria spinulosa (Leukhart 1849) are the most common species along the European coasts, locally building extensive reefs [5,8-10], such as in Mont Saint-Michel Bay, where it is possible to find the largest dimpled European 
reef (approximately 60,000 individuals $/ \mathrm{m}^{2}[16,17]$. In the Mediterranean, along the Italian coasts, S. alveolata forms mound-shaped reefs to large banks, while $S$. spinulosa generally forms smaller and isolated bioconstructions.

The presence of reefs, their development and temporal persistence are linked to many biotic (e.g., propagule pressure of Sabellaria planktonic larvae and their subsequent settlement) and abiotic factors (granulometry of the surrounding sediments, hydrodynamics and meteo-climatic regime). Propagules usually settle along the coastlines exposed to the proper action of tides, waves and currents. Indeed, a hydrodynamic regime must be sufficient to keep the sediment in suspension [18] but not tear off or erode the colony [19]. If temperature, salinity, nutrients, currents or other abiotic factors are optimal, the reef can have a constant growth [20]. After the first colony is established, it grows through particular mechanisms of recruitment in which adults induce the nearby rooting of larvae by producing organic glue similar to that used to form and cement tubes [9].

There are three main evolutionary stages of worm reefs: the phases of primary settlement, growth and erosion. Sabellaria alveolata and S. spinulosa reproduce throughout the year, with two principal reproductive peaks occurring in the spring and summer [18-21]. Attachment of larvae occurs in the presence of hard and stable substrates (both natural and artificial), but the colony can also grow on soft substrates [22]. A secondary settlement can arise during the growth phase and can help reef development. Growth begins when the tubes encrust the substrate, hence enlarging the colony horizontally [19]; after which, they also start growing perpendicularly to the seabed [23]. From the union of adjacent colonies, bioconstructions of different geometries and sizes are formed. These structures can become thick $(>1 \mathrm{~m})$ and wide $\left(>2 \mathrm{~km}^{2}\right.$; as in the case of the Mont Saint-Michel reef) platforms that can further evolve into real benches, whose shape and orientation vary according to the type of substrate and hydrodynamic regime [19], A classification of these structures was proposed by Griffin et al. [24] and was based on Gruet's morphological subdivision [8].

When the colony has reached a considerable size, and in relation to the seasonality, the process of physical degradation can occur due to the rapid and destructive action of storm waves, tides and marine currents. Nevertheless, Sabellaria reefs appear to have great shear strength by opposing external mechanical stresses [25]. The presence of erosive/destructive phases can be related to climate changes; anthropogenic disturbances (such as trampling, water pollution or aquaculture activities) and the presence of specific organisms such as fish, crabs, mussels and oysters that can colonize and erode bioconstructions [9].

At the microscale, the general framework of the reef is defined by two main elementary structural units [15,26,27]: (1) the sands cemented directly by the worms (the tube area that is ordered in concentrical layers- $t$ ) and (2) the sands that remain trapped between a tube and the adjacent one (the intertube area with elements irregularly arranged-i). According to the literature, the tube has a known three-layered structure with different sizes and shapes of cemented grains [27-29]. The grains of sand, the inner layer of the tube, cemented directly by the worm are mainly elongated, flattened and oriented tangentially to the development of the tubes. All the observations carried out at the microscale start from the recognition of this basic pattern. Using a multiscale approach (from general to microscale), the present paper compares two different large-scale bioconstructions built by sabellarian polychaetes along the Italian coast. The first is an area with a bioconstructions of S. spinulosa near Torre Mileto along the Southern Adriatic Coast, described as the largest bioconstruction of S. spinulosa in the Mediterranean area of the Northern Gargano Coast. The second area, localized near Ostia in the Central Tyrrhenian Sea, is characterized by the presence of $S$. alveolata reefs. New data are here presented, discussed and compared with complementary and already described data $[7,15,26,30]$, with the aim of: (i) analyzing the evolution in space and time of the reef. (ii) testing the reliability of technical procedures to describe the growth and destructive phases for a long period, (iii) defining a suitable classification for these types of structures and for the procedure proposed here, (iv) proposing procedural improvements adding simple and quantitative parameters and (v) developing seasonal growth models for the case studies observed here. 
The final aim of this work is the comparison of growth models of the two most widespread and stable worm reefs in the Mediterranean Sea over a long period of continuous monitoring (about eight years) in order to discriminate general and specific features related to the interactions between sedimentological, biological and anthropic processes.

\section{Study Area}

The studied areas are localized in Central-Southern Italy, along the coasts of the Adriatic and Tyrrhenian Seas (Figure 1).

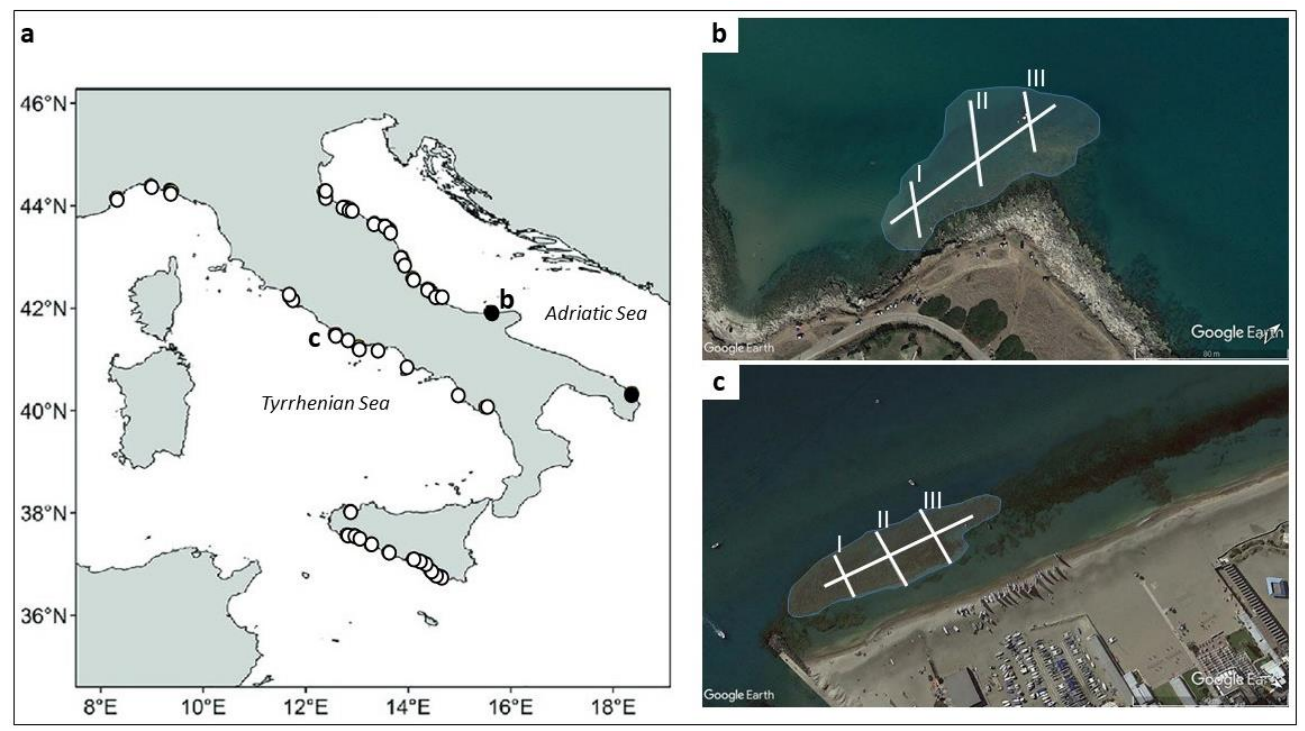

Figure 1. (a) Sabellaria alveolata (empty circles) and Sabellaria spinulosa (full circles) reefs along the Italian coast [31,32]. On the right, location of the sampling areas at (b) Torre Mileto and (c) Ostia. Four main observation transects are shown in white: one transect is parallel, and the other three are perpendicular to the coastline.

\subsection{Torre Mileto Site}

Sabellaria bioconstructions, found in the northern sector of the Gargano promontory, show well-developed formations between Torre Mileto $\left(41^{\circ} 55^{\prime} 45.3^{\prime \prime} \mathrm{N} ; 5^{\circ} 37^{\prime} 12.37^{\prime \prime} \mathrm{E}-\right.$ Figure $1 \mathrm{~b})$ and Vieste $\left(41^{\circ} 52^{\prime} 54.20^{\prime \prime} \mathrm{N} ; 1^{\circ} 10^{\prime} 27.07^{\prime \prime} \mathrm{E}\right)$. Sabellaria spinulosa is found along the northern coasts of the promontory. In the westernmost sector (at the east of Torre Mileto), bioconstructions are continuous or isolated mounds. Towards Vieste, bioconstructions are becoming more frequent, although thinner [33]. Bioconstructions better developed and more extended were observed near Torre Mileto, along the rocky shore between Lesina and Varano Lakes. In 2019, the site was proposed as "Sites of Community Importance" to protect them. In this area, the highest storm waves are recorded during the winter, and previous works indicated prevailing storm waves from the NNW and a longshore current that runs eastward [15].

\subsection{Ostia Site}

The site is characterized by the presence of a $S$. alveolata reef. It is strongly affected by the presence of the Tiber River, which influences the coastal dynamics of the entire area (more than $40 \mathrm{~km}$ toward the northern and southern sectors from the delta). The beaches, currently found near the river mouth, are sandy (mainly with a quartz-feldspathic component) with dune sections that can locally reach 10-12 $\mathrm{m}$ in height [34]. Near the reef, there is the so-called "Canale dei Pescatori", an ancient natural emissary of the Ostia swamp, which extends for about $8 \mathrm{~km}$ towards the inland and is currently dammed and used as a port and an outflow route of reclamation canals [34]. The long beach of Ostia Lido is located between the river and "Canale dei Pescatori" (Figure 1c). It is influenced 
by longitudinal transport towards the SE. The local tidal range is small $(<0.5 \mathrm{~m})$, and the closing depth of the beach profiles is $-7 \mathrm{~m}$ approximately. During the last few decades, the entire area has been affected by intense erosive phenomena due to the sediment flow variation of the Tiber River and, from 1990, a submerged longitudinal barrier of $2.5 \mathrm{~km}$ in length, built as a coastal defense [35]. The main S. alveolata bioconstruction at Ostia originated on basalt blocks of the artificial barrier.

\section{Materials and Methods}

Quantitative data and qualitative observations were acquired to describe the structures of the bioconstructions at macro- and microscale. The macroscale data were acquired directly in the field. The following elements were described/measured for each site during each survey:

- distributional area of the main bioconstruction (calculated in $\mathrm{m}^{2}$ ). Five georeferenced points were used to establish the approximate reef extension and its eventual lateral displacement;

- fragmentation degree. Across five test square areas $(3 \mathrm{~m} \times 3 \mathrm{~m})$, located in the same zone as the five georeferenced points, we used a qualitative scale assigning: (i) a low fragmentation value $(\mathrm{L})$ in the absence of interruptions, (ii) a moderate fragmentation value $(\mathrm{M})$ if the discontinuities in the presence of recurring structure interruptions are equal to $30 \%$ of the entire test area and (iii) a high fragmentation value $(\mathrm{H})$ in the presence of continuous structure interruptions higher than $50 \%$;

- the roughness of the bioconstruction surface, evaluated in the central portions of the bioconstruction and in the same five test square areas $(3 \times 3 \mathrm{~m})$. A high roughness value $(\mathrm{H})$ was assigned in the presence of highly articulated surfaces, an average roughness value $(M)$ for poorly articulated surfaces and a low roughness value $(L)$ when smooth surfaces covered more than $50 \%$;

- $\quad$ thickness, measured at five georeferenced points; the maximum thickness was measured in centimeters vertically by inserting a thin graduated iron rod into the bioconstruction.

At the microscale, the following parameters were measured (on a number of tubes between 70 and 150 for each season and for each site): (i) mean inner diameter of tubes composing the bioconstruction, defined as the arithmetic mean of average diameters in different seasons), (ii) variability coefficient, representing the ratio between the standard deviation and tubes on a square meter of surface, and (iii) the number of tubes/square meter.

The present paper reveals the results of 9 years (2012-2020) of monitoring by using the same procedures as in previous works. The surveys were performed over the last four weeks for each season, for a total of minimum four data for each season and site from 2012 to 2020 (Table 1). Choosing this timeframe allows us to monitor the effects of the entire season that is ending, the system mainly influenced by seasonal meteo-marine conditions. During all considered seasons, surveys were conducted to acquire photo and video materials and to measure the macroscale features of the bioconstruction along transects perpendicular to the coastline and parallel to the development of the bioconstructions in a bathymetric range between 1 and $5 \mathrm{~m}$ below the sea level. During the surveys, three sample replicates of reef fragments (minimum dimensions: $30 \times 30 \times 30 \mathrm{~cm}^{3}$ ) were collected for each season. In particular, samples were collected at different depths $(1 \mathrm{~m}, 2 \mathrm{~m}$ and $3 \mathrm{~m})$ along the central and highest part of the bioconstruction to describe the temporal geometrical development in more detail. For each sample, tubes with live polychaetes were analyzed from the base to the top. 
Table 1. This table summarizes the phases of the field analysis carried out from 2012 to 2020.

\begin{tabular}{|c|c|c|c|c|c|c|}
\hline Season & Year & Site & Survey & Mapping & Sampling & Macrofeat. Measuring \\
\hline Autumn & 2012 & Torre Mileto & $x$ & $x$ & $x$ & $x$ \\
\hline Spring & 2013 & Torre Mileto & $x$ & $x$ & $x$ & $\mathrm{x}$ \\
\hline Winter & 2013 & Torre Mileto & $x$ & $x$ & $x$ & $x$ \\
\hline Summer & 2015 & Torre Mileto & $x$ & $x$ & $x$ & $x$ \\
\hline Autumn & 2016 & Torre Mileto & $x$ & $x$ & $x$ & $x$ \\
\hline Spring & 2017 & Torre Mileto & $x$ & $x$ & $x$ & $x$ \\
\hline Summer & 2017 & Torre Mileto & $x$ & $x$ & $x$ & $x$ \\
\hline Autumn & 2017 & Torre Mileto & $x$ & $x$ & $x$ & $x$ \\
\hline Spring & 2018 & Torre Mileto & $x$ & $x$ & $x$ & $x$ \\
\hline Summer & 2018 & Torre Mileto & $x$ & $x$ & $x$ & $x$ \\
\hline Autumn & 2018 & Torre Mileto & $x$ & $x$ & & $x$ \\
\hline Winter & 2018 & Torre Mileto & $x$ & $x$ & & \\
\hline Spring & 2019 & Torre Mileto & $x$ & $x$ & $x$ & $x$ \\
\hline Summer & 2019 & Torre Mileto & $x$ & $x$ & $x$ & $x$ \\
\hline Autumn & 2019 & Torre Mileto & $x$ & $x$ & $x$ & $x$ \\
\hline Winter & 2019 & Torre Mileto & $x$ & $x$ & $x$ & $x$ \\
\hline Summer & 2020 & Torre Mileto & $x$ & $x$ & $x$ & $x$ \\
\hline Winter & 2020 & Torre Mileto & $x$ & $x$ & $x$ & $x$ \\
\hline Autumn & 2012 & Ostia & $x$ & $x$ & $x$ & $x$ \\
\hline Autumn & 2013 & Ostia & $x$ & $x$ & $x$ & $x$ \\
\hline Spring & 2014 & Ostia & $x$ & $x$ & $x$ & $x$ \\
\hline Summer & 2014 & Ostia & $x$ & $x$ & $x$ & $x$ \\
\hline Winter & 2014 & Ostia & $x$ & $x$ & & \\
\hline Spring & 2017 & Ostia & $x$ & $x$ & $x$ & $x$ \\
\hline Spring & 2018 & Ostia & $x$ & $x$ & $x$ & $x$ \\
\hline Summer & 2018 & Ostia & $x$ & $x$ & $x$ & $x$ \\
\hline Autumn & 2018 & Ostia & $x$ & $x$ & $x$ & $x$ \\
\hline Winter & 2018 & Ostia & $x$ & $x$ & $x$ & $x$ \\
\hline Spring & 2019 & Ostia & $x$ & $x$ & $x$ & $x$ \\
\hline Summer & 2019 & Ostia & $x$ & $x$ & $x$ & $x$ \\
\hline Autumn & 2019 & Ostia & $x$ & $x$ & $x$ & $x$ \\
\hline Winter & 2019 & Ostia & $x$ & $x$ & $x$ & $x$ \\
\hline Summer & 2020 & Ostia & $x$ & $x$ & $x$ & $x$ \\
\hline Winter & 2020 & Ostia & $x$ & $x$ & & $x$ \\
\hline
\end{tabular}

All samples were treated with epoxy resin and then cut along the main tube growth axis to obtain slices that, once polished, were used to study the vertical development of the reef. After a detailed description, slices were used to acquire a high-resolution image using a scanner. The methodology used to acquire petrographical and granulometric data by image analysis on slices and thin sections has already been described in previous works $[15,30]$. High-resolution scans of thin sections allowed us to describe the worm reef framework at the microscale and in different seasons. Using Image ${ }^{\odot}{ }^{\circ}$, the morphometric features were a total of about eighteen hundred tubes per species. Furthermore, about the same samples of annual and seasonal variations were analyzed. Tube width, mean diameter for each thin section, coefficient of variation and tube density were the main morphometric elements evaluated in the thin sections.

\section{Results}

\subsection{Large-Scale Monitoring Results}

The monitoring of worm reefs was focused on the assessment of four physical parameters: extension, fragmentation, roughness and maximum thickness. The variations of the mean values of the macroscale parameters during different seasons and years are shown in Figure 2. 


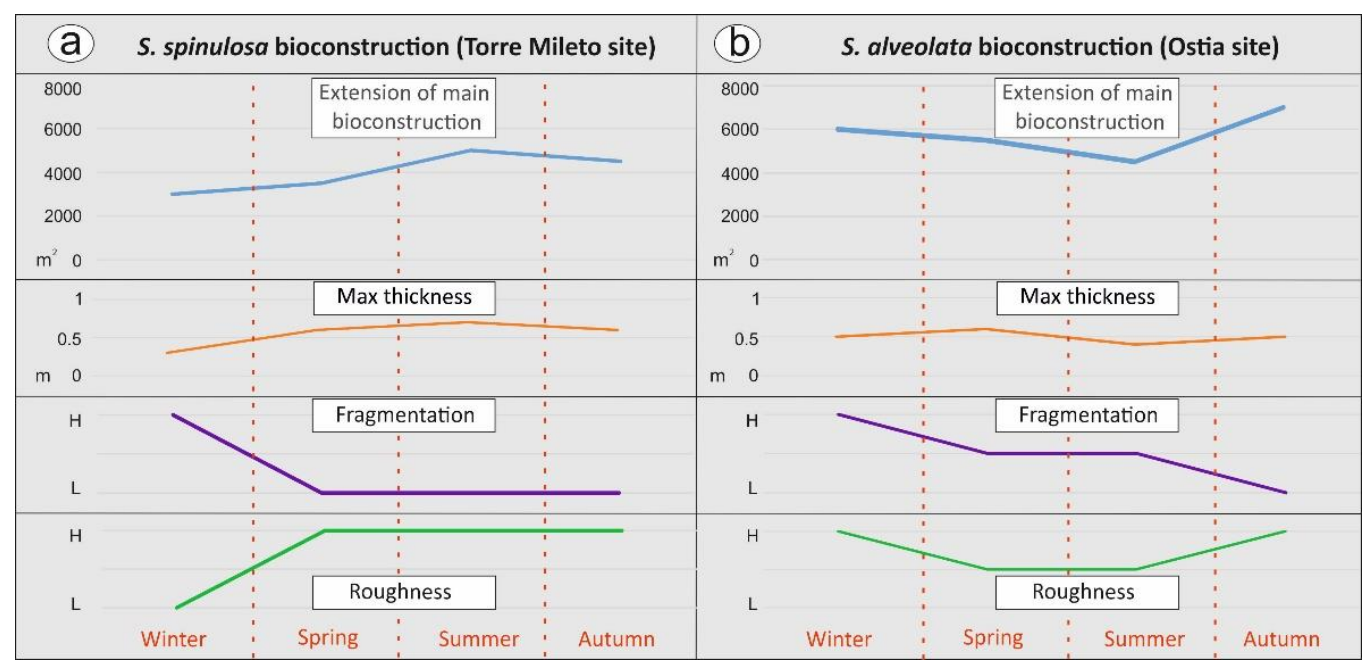

Figure 2. Variations of the mean values of the macroscale parameters during different seasons and years. Diagram shows the variation trends of the parameters during different seasons, including extension; maximum thickness; fragmentation (using a qualitative scale: low fragmentation (L), moderate fragmentation $(\mathrm{M})$ and high fragmentation $(\mathrm{H})$ ) and roughness (using a qualitative scale: high roughness $(\mathrm{H})$, moderate roughness $(\mathrm{M})$ and low roughness $(\mathrm{L})$ ). On the left is the main bioconstruction of S. spinulosa at Torre Mileto (a). On the right is the S. alveolata bioconstruction at Ostia (b).

The results indicate that the main S. spinulosa bioconstruction at Torre Mileto reached its greatest extent between the spring and summer (maximum measured value $5300 \mathrm{~m}^{2}$ ). However, the extent decreased in the autumn (on average, about $4200 \mathrm{~m}^{2}$ ) and was drastically reduced in the winter (maximum measured value $2300 \mathrm{~m}^{2}$ ). The intensity of fragmentation was low during the spring, summer and autumn while high in the winter. The bioconstruction surfaces appeared very smooth in the winter while highly articulated in the other seasons. Values of the maximum thicknesses were comparable between the spring, summer and autumn (maximum measured value $0.75 \mathrm{~cm}$ ) but significantly decreased in the winter (maximum measured value 0.25 ).

The main S. alveolata bioconstruction at Ostia reached its maximum extension in the autumn (maximum measured value $7200 \mathrm{~m}^{2}$ ) and decreased with the same intensity during all the other seasons (maximum measured value $4400 \mathrm{~m}^{2}$ ). Fragmentation of the bioconstruction decreased during the spring and summer and increased from the autumn to winter. The presence of smooth and eroded surfaces was less visible compared to the bioconstruction of Torre Mileto but showed a presence of more articulated areas between the autumn and winter. Finally, values of the maximum thicknesses were comparable during all the analyzed seasons, although slight variations were observed between the spring (maximum measured value $0.65 \mathrm{~cm}$ ) and summer (minimum measured value $0.4 \mathrm{~cm})$.

\subsection{Meso- and Microscopic Monitoring Results}

The mesoscale physical features associated with the growth of the reef of both species were analyzed using decimetric polished slabs. In particular, the slabs that were cut perpendicular to the base of the reef showed vertical development of the worm tubes (Figure 3). The growth of the reef was the result of both the vertical development of adjacent tubes and the continuous infill of intertube areas with sand. The upward-directed growth (see arrow in Figure 3) of the reef occurred along quasivertical directions, even if the actual angle seemed to slightly change over time (Figure 3). The slabs of the large-scale samples showed also an alternation of lighter and darker bands. Darker bands, connected to an abundance of organic matter, (green areas in Figure 3B) have a sharp top, while their base is more gradual. The sharp top of the darker sectors mainly corresponds to the interruption of worm tubes (red dotted line in Figure 3B) and to slight variations in the tube growth direction. 


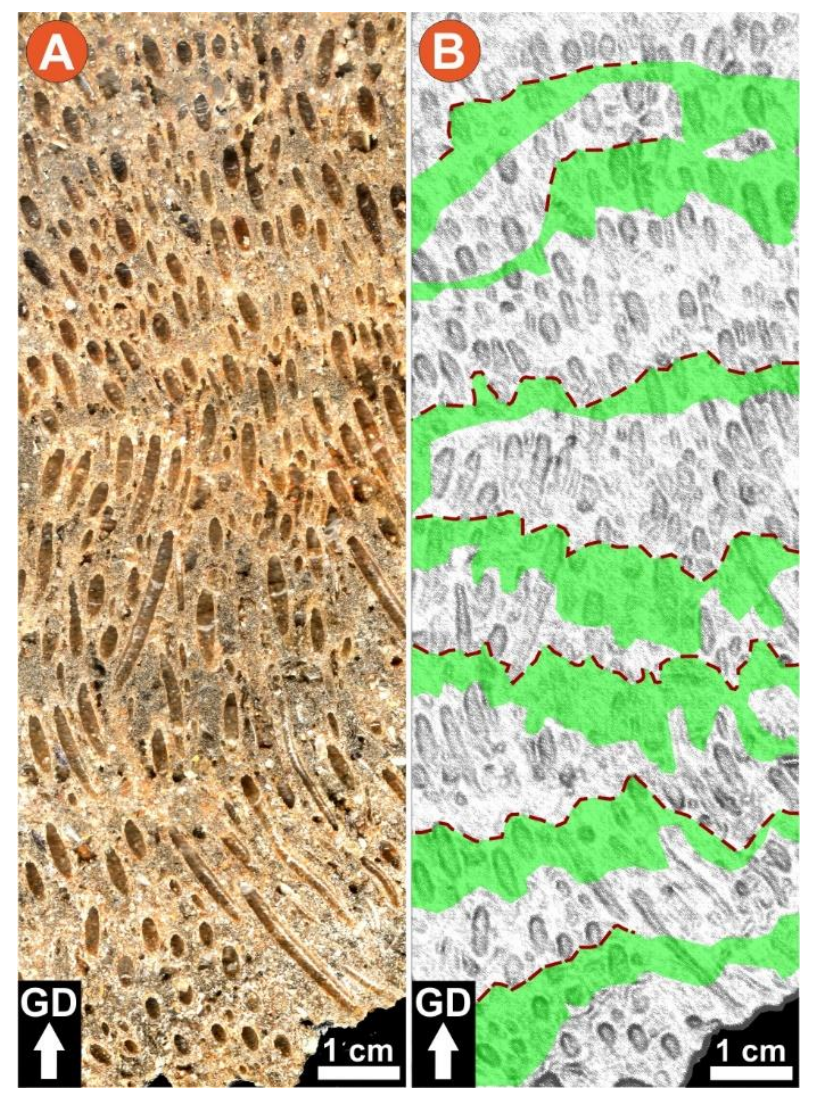

Figure 3. Mesoscopic analysis on slab cuts along the growth direction (GD, white harrow in the lower left corner) of the Torre Mileto reef. (A) Note the presence of irregular alternance of the lighter and darker intervals and the slight changes in the angle of the growth direction. (B) The darker parts are highlighted in green. Note that their irregular and sharp tops (red dotted lines) correspond to some tube interruptions.

At the microscale, we were able to detail stages of the vertical development of the worm reef with the petrographic observations in the thin section (Figure 4). In particular, Figure 5 shows the substantial variations of the main morphometric features measured in the fragments of reef sampled in Torre Mileto (S. spinulosa) and Ostia (S. alveolata): the average values obtained for each season in the mean of eight years diameter and the cohefficient of variation of the tube width and tube density as the average values were compared.

Regarding the S. spinulosa bioconstruction, intermediate values of the tube diameters were observed during the winter (about $1800 \mathrm{m \mu}$ ). In the following months, however, this value gradually decreased until reaching its minimum in the summer (about $1200 \mathrm{~m} \mu$ ) and then increasing again. The variability of the measured diameters was low from the winter to summer (about 0.27 ) but increased during the autumn (0.41). Finally, the average tube frequency per $\mathrm{m}^{2}$ rapidly increased from the winter (about 55,000 tubes $/ \mathrm{m}^{2}$ ) to autumn (about 165,000 tubes $/ \mathrm{m}^{2}$ ).

The microstructure of Ostia's bioconstruction showed some variation compared to Torre Mileto. The highest mean diameter value was measured in the summer (about $1900 \mathrm{m \mu}$ ), which then slowly decreased in the autumn (about $1100 \mathrm{m \mu}$ ) and during subsequent seasons. The variability of the tube sizes was high in the autumn and winter (about 0.80 ) and slowly decreased in the following seasons until reaching its lowest values in the summer (about 0.20 ). The average tube frequency in $\mathrm{m}^{2}$ increased slowly from the winter (about 40,000 tubes $/ \mathrm{m}^{2}$ ) to autumn (about 155,000 tubes $/ \mathrm{m}^{2}$ ).

For both species, wormless tubes filled with sediment were observed during the winter (about $7-12 \%$ of the total tubes) and were almost absent during other seasons. 
Finally, the analyzed microscopic reef framework in the thin section confirmed two main sectors: the tube and intertube. The tube was built using grains of variable dimensions by the function of age (see References [15,30]). The intertube area (which was comprised of adjacent tubes) was filled with sand with textural parameters that fairly differed from the grains of the tube. Generally, intertube sands are coarser-grained and less sorted than tube sands.
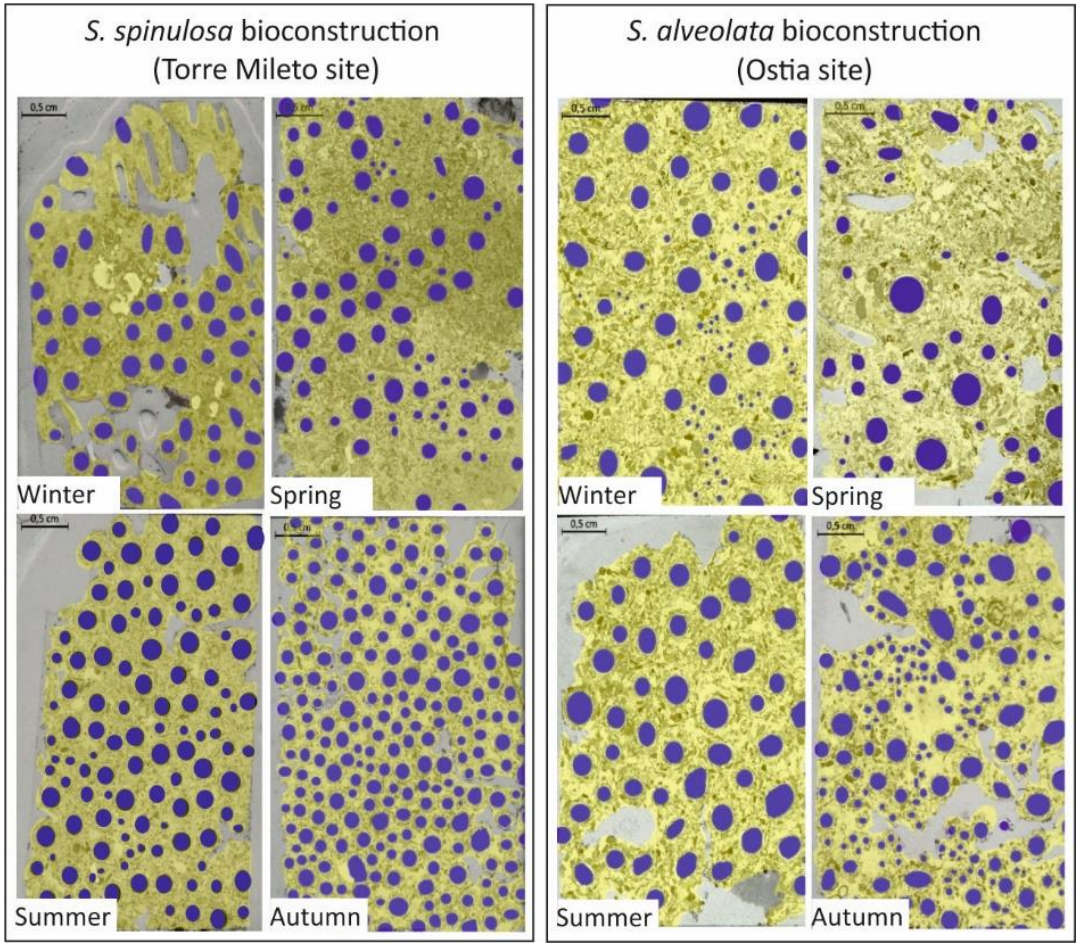

Figure 4. Digitized thin sections for the image analysis. On the left, an example of the four-season sections of the Torre Mileto site. On the right, an example of the four-seasons sections of the Ostia site. The lumina of the tubes are highlighted in blue and the sediment trapped in the bioconstruction in yellow.

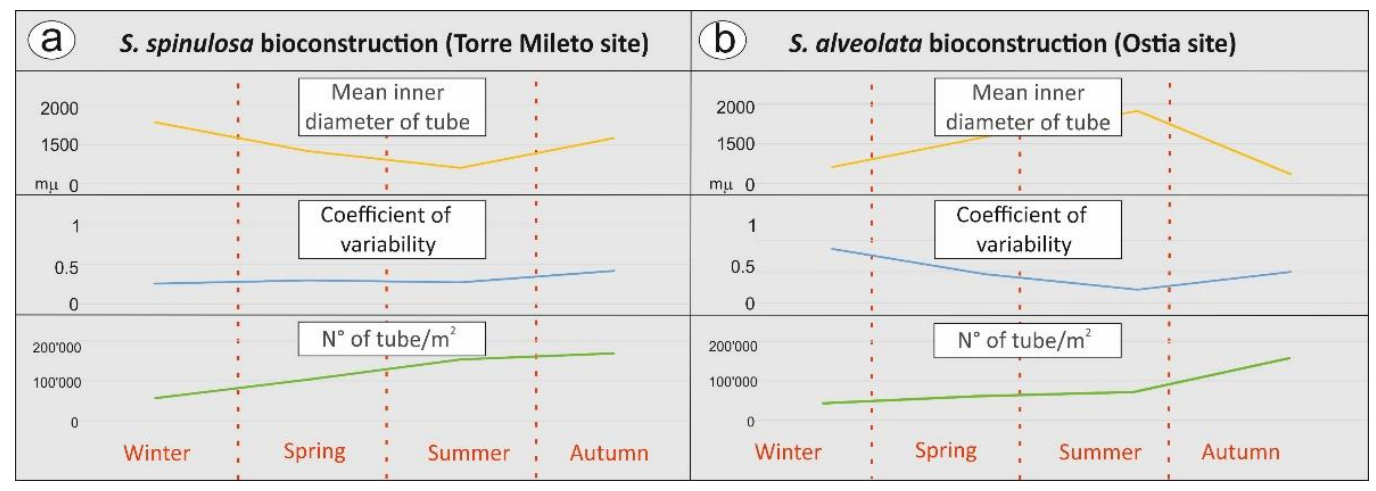

Figure 5. The variations in the mean value of the microscale parameters during different seasons and years (9). The diagram shows the variation trends of the parameters of the mean diameter of the tubes, the coefficient of variability and the number of tubes per $\mathrm{m}^{2}$ of the bioconstruction during the different seasons. On the left, the main bioconstruction in S. spinulosa in Torre Mileto (a), and on the right, the one in S. alveolata at Ostia (b). 


\section{Discussion}

\subsection{A Stage-Based Model for the Temporal/Spatial Evolution of the Worm Reefs}

The general macroscale features of the bioconstruction at Torre Mileto were highly variable over the seasons. A dramatic decrease in the extension and thickness of this bioconstruction has always occurred in the winter, while these parameters gradually increased from the spring. During the winter, the bioconstruction always appeared strongly fragmented and with smooth surfaces.

At Ostia, the distributional area and thicknesses of bioconstruction had comparable values throughout the year. Roughness, however, was subject to a drastic decline during the spring and summer. Fragmentation decreased slowly, starting from the winter and continuing until the following autumn.

At the microscale, the measured parameters were closely related to the characteristics of the two different species. The general microstructure appeared the same as described by Lisco et al. [15]. It was characterized by an area in which the grains are directly cemented by the worm and an area interposed between adjacent tubes, filled by loose sediments. Furthermore, the precise granulometric range characterizes the microstructure in both species for the two different sectors (tube and intertube areas). Finally, the structures are usually made of flattened, elongated and porous granules. The average diameters of S. spinulosa were always small during the summer and then increased from the autumn until the winter, when the parameter recorded its highest values. The estimated number of tubes per $\mathrm{m}^{2}$ and the variability coefficient demonstrated a similar trend. Indeed, they gradually increased from the beginning to the end of the year. The microscale parameters of $S$. alveolata demonstrated inverse trends compared to S. spinulosa. These trends were cyclical over seasons and were verified during the entire study period.

Nine-year monitoring, along with the analysis of the samples, allowed the elaboration of evolution models at different observational scales. All observations were combined to demonstrate the existence of seasonal alternations in the growth and degenerative phases. However, these phases may have different intensities depending on the conditions of the associated benthic community, succession of exceptional weather events and anthropogenic action (both fishing and trampling). Furthermore, an analysis of the microstructure along the vertical sections revealed the presence of surfaces that originated after erosional events, and the underlying brownish interval could represent degenerative phases. At the macroscale, the degenerative phase was characterized by: (i) a reduction of the surface area occupied by the main bioconstruction, (ii) increased fragmentation, (iii) the presence of leveled upper surfaces and (iv) low thicknesses. At the mesoscale, the degenerative or stasis phases seemed to be associated with the occurrence of darker intervals, where the were are interrupted and the growth seemed to restart with different directions. At the microscale, the degenerative phases were recognizable by (i) the presence of large diameter tubes, (ii) low variability of their size, (iii) low total number and (iv) a high number of tubes filled with sand.

The growth phase can be recognized by field measurements of: (i) an increase in the surface area occupied by the main bioconstruction, (ii) a relative increase in the bioconstruction continuity, (iii) the presence of highly articulated upper surfaces and (iv) an increase of the bioconstruction thicknesses. On decimeter-thick slabs, growth intervals are marked by lighter sectors and the continuous vertical development of worm tubes. At the microscale, the reef growth phase showed: (i) a slight decrease in the maximum tube diameter, (ii) a great variability of the tube sizes, (iii) a high total number of tubes and (iv) the absence of tubes filled with sand.

Using the results coming from the analysis carried out on two different worm reefs, we are able to trace the evolution of the Ostia (Sabellaria alveolata reef) and Torre Mileto (Sabellaria spinulosa reef) sites by discussing their significant differences in terms of the seasonal occurrences of the growth and decline phases. In fact, although the structures are very similar in both sites, their evolutionary stages are essentially opposite during the year, 
apparently recording the same processes but during different seasons. The evolutionary model in Figure 6 summarizes these differences at different observational scales.

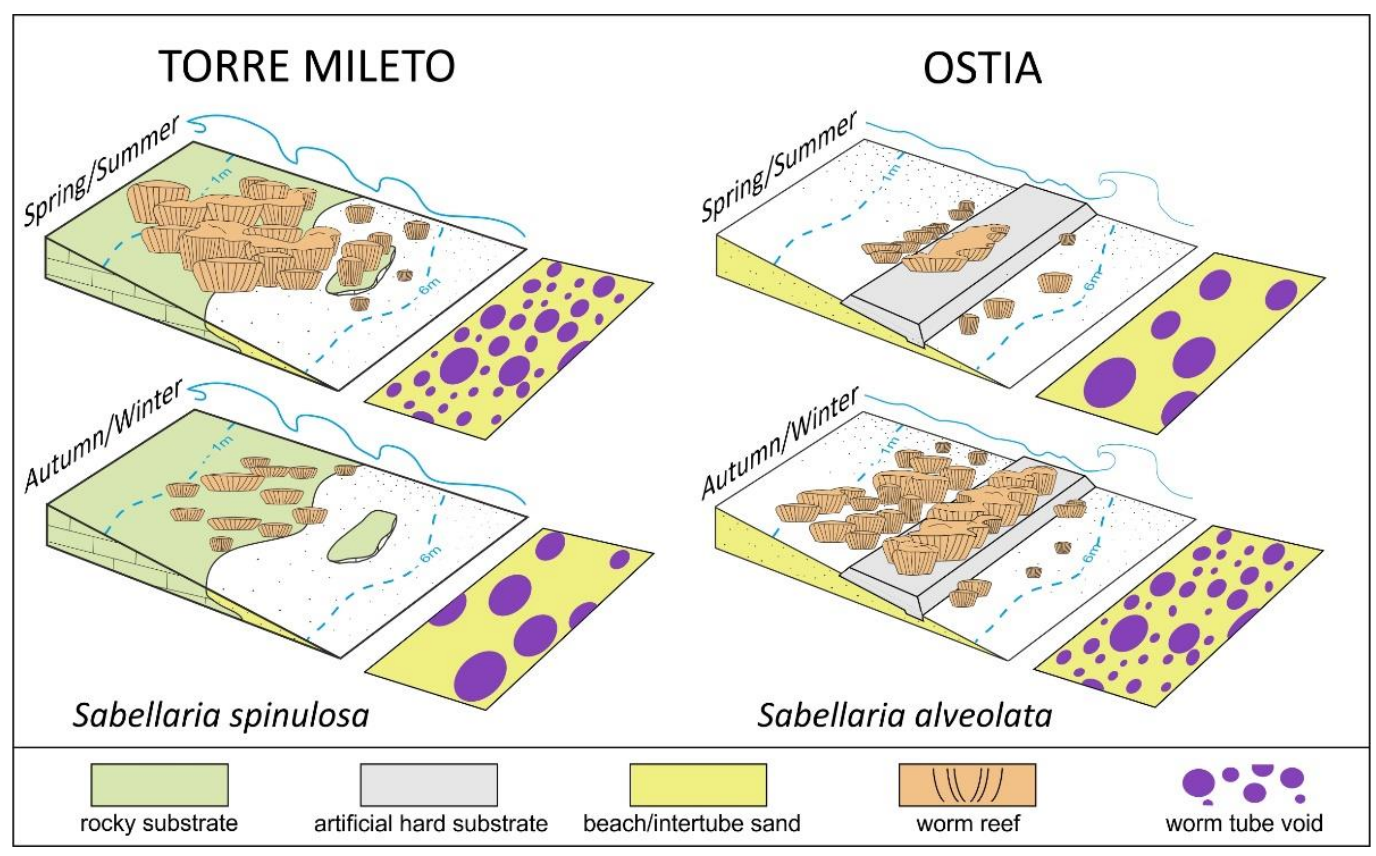

Figure 6. The evolutionary models of Sabellarian reefs. On the left, the sketch of the S. spinulosa bioconstruction of Torre Mileto (at the top during the summer and spring seasons, the growth phase; below, during the autumn and winter seasons, the degenerative phase). On the right, the sketch of the S. alveolata bioconstruction of Ostia (at the top during the summer and spring seasons, the degenerative phase; below, during the autumn and winter seasons, the growth phase). Each phase is represented at the macroscale and in a sketch of the arrangement of the voids at the microscale.

The Sabellaria spinulosa reef of Torre Mileto records intense periods of growth and decline. In the winter, the reef is deeply eroded by the action of storm waves, and the adjacent foreshore environments contain abundant aggregates of worm tubes. Younger organisms are not able to clink on the reef, and only adult worms survive to this degenerative phase.

At this stage, the abundance of tubes filled by sand probably preserve the reef by complete erosion. During the summer, the reef area is not subject to severe storm waves events. New and old generations of worms coexist and support the growth of the reef, which can reach relevant rates (tens of $\mathrm{cm}$ in 3 months). The anthropic action is not relevant even in the summer, since the reef area is not frequented by beach bathers.

The Sabellaria alveolata reef of Ostia seemed generally stable during the monitoring period, recording slight stasis or degenerative phases only during the summer. In this season, Ostia Beach is subject to an impressive human pressure related with the bathing season and direct trampling actions also on the artificial barrier. The reef fragments that eventually reach the foreshore are suddenly destroyed by deep cleaning operations that are ordinary in public and private bathing beaches. The engraftment of new generations on the pre-existing bioconstruction is not favored. During the winter, the actions of storm waves do not deeply influence the growth, since the presence of the artificial barrier mitigates their effects.

Other environmental (physical, biological and human) parameters seem to be similar in both sites. The spawning and recruitment phases are generally present all-year-round but are more concentrated in the spring and summer, depending on the species and local conditions [21,22,36,37]; therefore, this does not represent a difference between the two sites. Only for a brief phase in Torre Mileto (2014), the presence of mussels significantly reduced the population of Torre Mileto worms, but generally, both species do not seem to have undergone degeneration phases linked to other species. 
Furthermore, we have no evidence of particular episodes of pollution, although the Ostia area undoubtedly suffers greater anthropogenic pressure. All data showed that the Sabellaria reef environment for both species seems to be dominated by a finite number of variables (physical, biological and anthropic processes) that can be evaluated with a detailed multiscale and multitemporal approach.

\subsection{Towards an Integrated Approach for the Description of Growth/Degenerative Phases of Worm Reefs}

Aiming at the creation of a final model that would take into account all the results achieved at the macro-, meso- and microscales, the present study suggests a new qualitative/quantitative classification of the "reef evolutionary stages" based on seasonal variations of the main volumetric and textural features of Sabellaria bioconstructions. This classification is composed of two terms:

1. all macroscale observations and data (it partially modifies the classification proposed by Griffin et al. [24] by adding several new parameters (Table 3);

2. microscale textural features (Table 2).

Table 2. Summary table of the microscale features proposed in this work.

\begin{tabular}{cl}
\hline Microscale Features & \multicolumn{1}{c}{ Description } \\
\hline E & $\begin{array}{l}\text { Inner mean diameter of tubes composing bioconstruction. It is } \\
\text { defined as the arithmetic mean of the average tube diameters in } \\
\text { different seasons. }\end{array}$ \\
\hline F & $\begin{array}{l}\text { Coefficient of variation as a measure of the relative variability. It is } \\
\text { defined as the ratio of the standard deviation of mean (average) } \\
\text { tube values for one square meter of surface. }\end{array}$ \\
\hline G & Number of tubes/square meter. \\
\hline H & Presence/absence of tubes filled with external random sediment. \\
\hline
\end{tabular}

Table 3. Summary table of the macroscale features proposed in this work.

\begin{tabular}{cl}
\hline Macroscale Features & \multicolumn{1}{c}{ Description } \\
\hline A & $\begin{array}{l}\text { Variation in the overall distributional area of the } \\
\text { main bioconstruction. }\end{array}$ \\
\hline B & $\begin{array}{l}\text { Fragmentation degree of the main bioconstruction. It is a } \\
\text { qualitative measure carried out in the central portion of the } \\
\text { bioconstruction based on three classes of relative lateral reef } \\
\text { continuity: low fragmentation (L), moderate fragmentation }(\mathrm{M}) \text { and } \\
\text { high fragmentation }(\mathrm{H}) \text { values. }\end{array}$ \\
& $\begin{array}{l}\text { Roughness of the bioconstruction surface. It is a qualitative } \\
\text { measure carried out in the central portion of the bioconstruction } \\
\text { and is based on three classes: high roughness (H), moderate } \\
\text { roughness }(\mathrm{M}) \text { and low roughness (L) values. }\end{array}$ \\
\hline C & Thickness.
\end{tabular}

The combination of these two terms seems to adequately describe the evolutionary stages of Sabellaria reefs.

\section{Concluding Remarks}

Sabellaria bioconstructions show high seasonal variability in the main physical parameters. In a few days, large-scale reefs can be deeply modified or even destroyed by storm wave action, able to reduce them into small, isolated colonies occupying only hard substrate sectors. Bioconstructions can also rapidly regenerate and, in few months, can reach $50 \mathrm{~cm}$ 
in height and colonize new substrates. Moreover, bioconstructions can suffer from gradual or sudden destruction phases due to the influence of various factors, including storms, competition with other organisms and anthropic pressures.

The evolutionary model of the Sabellarian reef is composed of two alternating phases: (a) a degenerative phase in which the bioconstruction is divided into numerous isolated colonies of varying sizes and (b) a growth phase in which the reef extends over large areas and colonizes sandy substrates; in this phase, the reef is laterally continuous, and its surface is strongly articulated. These phases can almost always be recognized, although they show small differences due to the specific characteristics of S. alveolata and S. spinulosa and slight variations of the bathymetric ranges in which these species occur.

Bioconstructions interplay with the physical dynamics of the beaches in different, specific ways and positively influence the natural nourishment of coastal areas. The cycles are linked to the phases of reproduction, the physical actions of storms and the anthropogenic impacts, and although developed at different times, their dynamics are very similar. Descriptions of the current evolution models of this bioconstruction type are necessary to understand the evolution of these fragile environments, fundamental for coastal dynamics.

The procedure model proposed represents a useful tool for monitoring these structures. Indeed, this work identified the monitoring parameters useful for classifying the state of preservation of Sabellaria bioconstruction. The microscopic analyses alone proved to be sufficient for this purpose, and if performed on bioconstructions with detectable extension and thickness during seasonal cycles, they could completely replace monitoring.

Author Contributions: Conceptualization, S.N.L. and M.M.; methodology, S.N.L., M.M., C.P., A.B. and P.A.; software, S.N.L. and T.L.; validation, M.M. and M.F.G., formal analysis, S.N.L., C.P. and T.L.; investigation, S.N.L., C.P., T.L. and A.B.; resources, M.M.; data curation, M.M.; writing-original draft preparation, S.N.L. and M.M.; writing-review and editing, S.N.L., M.M., C.P. and T.L., visualization, S.N.L.; supervision, M.M., M.F.G. and A.G., project administration, M.M. and funding acquisition, M.M. All authors have read and agreed to the published version of the manuscript.

Funding: This research received no external funding.

Conflicts of Interest: The authors declare no conflict of interest.

\section{References}

1. Ten Hove, H.A.; Van Den Hurk, P. A review of recent and fossil serpulid 'reefs'; actuopalaeontology and the 'Upper malm' serpulid limestones in NW Germany. Geologie en Mijnbouw 1993, 72, $23-67$.

2. Sanfilippo, R.; Vertino, A.; Rosso, A.; Beuck, L.; Freiwald, A.; Taviani, M. Serpula aggregates and their role in deep-sea coral communities in the southern Adriatic Sea. Facies 2013, 59, 663-677. [CrossRef]

3. Gruet, Y.; Bodeur, Y. Sélection des grains de sable selon leur nature et leur forme par Sabellaria alveolata (Linné) (Polychète Sabellariide) lors de la reconstruction expérimentale de son tube. Mémoires du Muséum National d'Histoire Naturelle 1994, 162, 425-432.

4. Vovelle, J. Le tube de Sabellaria alveolata (L.) Annélide Polychète Hermellidae et son ciment. Étude écologique, expérimentale, histologique et histochimique. Archives de Zoologie Expérimentale et Générale 1965, 106, 1-180.

5. Dubois, S.; Laurent, B.; Cognie, B.; Beninger, P.G. Particle capture and processing mechanism in Sabellaria alveolata (Polychaeta: Sabellariidae). Mar. Ecol. Prog. Ser. 2005, 301, 159-171. [CrossRef]

6. Naylor, L.A.; Viles, H.A. A temperate reef builder: An evaluation of the growth, morphology and composition of Sabellaria alveolata (L.) colonies on carbonate platforms in South Wales. In Carbonate Platform Systems: Components and Interactions; Insalaco, E., Skelton, P.W., Palmer, T.J., Eds.; Geological Society, Special Publications: London, UK, 2000; Volume 178, pp. 9-19.

7. Bonifazi, A.; Lezzi, M.; Ventura, D.; Lisco, S.N.; Cardone, F.; Gravina, M.F. Macrofaunal biodiversity associated with different developmental phases of a threatened Mediterranean Sabellaria alveolata (Linnaeus, 1767) reef. Mar. Environ. Res. 2019, 145, 97-111. [CrossRef] [PubMed]

8. Gruet, Y. Spatio-temporal changes of Sabellarian reefs built by the sedentary Polychaete Sabellaria alveolata (LINNE). Marine Ecology. Pubblicazioni della Stazione Zoologica di Napoli 1986, 73, 303-319. [CrossRef]

9. Holt, T.J.; Rees, E.I.; Hawkins, S.J.; Seed, R. Biogenic reefs (volume IX). In An Overview of Dynamic and Sensitivity Characteristics for Conservation Management of Marine SACs; Scottish Association for Marine Science (UK Marine SACs Project): Oban, UK, 1998; 170p.

10. Nicoletti, L.; Lattanzi, L.; La Porta, B.; La Valle, P.; Gambi, M.C.; Tomassetti, P.; Tucci, P.; Chimenz Gusso, C. Sabellaria reefs from the Latium coast (Central Tyrrhenian Sea). Biologia Marina Mediterranea 2001, 8, 252-258. 
11. Dubois, S.; Comtet, T.; Retière, C.; Thiébaut, E. Distribution and retention of Sabellaria alveolata larvae (Polychaeta: Sabellariidae) in the bay of Mont Saint Michel, France. Mar. Ecol. Prog. Ser. 2007, 346, 243-254. [CrossRef]

12. Delbono, I.; Bianchi, C.N.; Morri, C. Le biocostruzioni di Sabellaria alveolata come indicatori ambientali: Area costiera fra Chiavari e Sestri Levante. In Studi per la Creazione di Strumenti di Gestione Costiera; Ferretti, O., Ed.; Golfo del Tigullio: Genoa, Italy, 2003; pp. 130-140.

13. Braithwaite, C.J.R.; Robinson, R.J.; Jones, G. Sabellarids: A hidden danger or an aid to subsea pipelines? Q. J. Eng. Geol. Hydrogeol. 2006, 39, 259-265. [CrossRef]

14. La Porta, B.; Nicoletti, L. Sabellaria alveolata (Linnaeus) reefs in the Central Tyrrhenian Sea (Italy) and associated polychaete fauna. Zoosymposia 2009, 2, 527-536. [CrossRef]

15. Lisco, S.; Moretti, M.; Moretti, V.; Cardone, F.; Longo, C.; Corriero, G. Sedimentological features of Sabellaria spinulosa bioconstructions. Mar. Pet. Geol. 2017, 87, 203-212. [CrossRef]

16. Desroy, N.; Dubois, S.; Fournier, J.; Ricquiers, L.; Le Mao, P.; Guérin, L.; Gerla, D.; Rougerie, M.; Legendre, A. Conservation status of Sabellaria alveolata (L.) (Polychaeta: Sabellariidae) reefs in the Mont-saint-Michel bay. Aquat. Conserv. Mar. Freshw. Ecosyst. 2011, 21, 462-471. [CrossRef]

17. Schlund, E.; Basuyaux, O.; Lecornu, B.; Pezy, J.P.; Baffreau, A.; Dauvin, J.C. Macrofauna associated with temporary Sabellaria alveolata reefs on the west coast of Cotentin (France). SpringerPlus 2016, 5, 1260-1281. [CrossRef]

18. Ayata, S.D.; Ellien, C.; Dumas, F.; Dubois, S.; Thiébaut, É. Modelling larval dispersal and settlement of the reef-building polychaete Sabellaria alveolata: Role of hydroclimatic processes on the sustainability of biogenic reefs. Cont. Shelf Res. 2009, 29, 1605-1623. [CrossRef]

19. Gruet, Y. Aspects morphologiques et dynamiques de constructions de l'annelide polychete Sabellaria alveolata (Linne). Revue des Travaux de l'Institut des Pêches Maritimes 1972, 36, 131-161.

20. Allen, J.H.; Billings, I.; Cutts, N.; Elliott, M. Mapping, Condition E Conservation Assessment of Honeycomb Worm, Sabellaria alveolata Reefs on the Eastern Irish Sea Coast; Report to English Nature, Reference No: Z122-F-2002; Institute of Estuarine and Coastal Studies University of Hull: Hull, UK, 2002.

21. Lezzi, M.; Cardone, F.; Mikac, B.; Giangrande, A. Variation and ontogenetic changes of opercularpaleae in a population of Sabellaria spinulosa (Polychaeta: Sabellariidae) from the South Adriatic Sea, with remarks on larval development. Sci. Mar. 2015, 79, 1-14.

22. Pearce, B.; Hill, J.M.; Wilson, C.; Griffin, R.; Earnshaw, S.; Pitts, J. Sabellaria spinulosa Reef Ecology and Ecosystem Services; The Crown Estate: London, UK, 2011; p. 120. ISBN 978-1-906410-27-8.

23. Gruet, Y.; Bodeur, Y. Ecological conditions of modern sabellarian reefs development: Geological implications. Pubbl. Serv. Géol. Lux 1995, 29, 73-80.

24. Griffin, R.A.; Jones, R.E.; Lough, N.E.L.; Lindenbaum, C.P.; Alvarez, M.C.; Clark, K.A.J.; Griffiths, J.D.; Clabburn, P.A.T. Effectiveness of acoustic cameras as tools for assessing biogenic structures formed by Sabellaria in highly turbid environments. Aquat. Conserv. Mar. Freshw. Ecosyst. 2020, 30, 1121-1136. [CrossRef]

25. Le Cam, J.B.; Fournier, J.; Etienne, S.; Couden, J. The strength of biogenic sand reefs: Visco-elastic behaviour of cement secreted by the tube building polychaete Sabellaria alveolata, Linnaeus, 1767. Estuar. Coast. Shelf Sci. 2011, 91, 333-339. [CrossRef]

26. Lisco, S.; Acquafredda, P.; Gallicchio, S.; Sabato, L.; Bonifazi, A.; Cardone, F.; Corriero, G.; Gravina, M.F.; Pierri, C.; Moretti, M. The sedimentary dynamics of Sabellaria alveolata bioconstructions (Ostia, Tyrrhenian Sea, central Italy). J. Palaeogeogr. 2020,9 , 2. [CrossRef]

27. Sanfilippo, R.; Rosso, A.; Mastandrea, A.; Viola, A.; Deias, C.; Guido, A. Sabellaria alveolata sandcastle worm from the Mediterranean Sea: New insights on tube architecture and biocement. J. Morphol. 2019, 280, 1839-1849. [CrossRef] [PubMed]

28. Scholl, D.W. Effects of an arenaceous tube- building polychaete upon the sorting of a beach sand at Abalone Cove, California. Canpass Mag. 1958, 35, 276-283.

29. Bodeur, Y.; Garcin, M.; Gruet, Y.; Vachard, D. Biosédimentologiedes Constructions à Hermelles de l'île de Noirmoutier (France). Relations Avec des Équivalents Fossiles Découverts Dans le Messinien des Cordillères Bétiques (Espagne), 8th ed.; IAS: Tunis, Tunisia, 1987; 2p.

30. Gravina, M.F.; Chimienti, G.; Longo, C.; Corriero, G.; Lisco, S.; Moretti, M.; Cardone, F.; Nonnis Marzano, C.; Bertrandino, M.; Giangrande, A.; et al. Sabellaria spinulosa (Annelida, Polychaeta) reefs in the Mediterranean Sea: Habitat mapping, dynamics and associated fauna for conservation management. Estuar. Coast. Shelf Sci. 2018, 200, 248-257. [CrossRef]

31. Ingrosso, G.; Abbiati, M.; Badalamenti, F.; Bavestrello, G.; Belmonte, G.; Cannas, R.; Benedetti-Cecchi, L.; Bertolino, M.; Bevilacqua, S.; Bianchi, C.N.; et al. Mediterranean Bioconstructions Along the Italian Coast. Adv. Mar. Biol. 2018, 79, 61-136. [CrossRef] [PubMed]

32. Sanfilippo, R.; Guido, A.; Insacco, G.; Deias, C.; Catania, G.; Reitano, A.; Leonardi, R.; Rosso, A. Distribution of Sabellaria alveolata (Polychaeta Sabellariidae) in the Mediterranean Sea: Update and new findings. Zoosymposia. In Proceedings of the $13^{\circ}$ IPC Conference, Long Beach, CA, USA, 2-8 August 2019; Volume 19, pp. 198-208.

33. BIOMAP Project. Biocostruzioni Marine in Puglia. 2014. Available online: http://www.sit.puglia.it/portal/portale_rete_ ecologica/biomap (accessed on 20 July 2021).

34. Capelli, G.; Mazza, R.; Papiccio, C. Intrusione salina nel Delta del Fiume Tevere. Geologia, idrologia e idrogeologia del settore romano della piana costiera. Giornale di Geologia Applicata 2007, 5, 13-28. 
35. Franco, L.; Di Risio, M.; Riccardi, C.; Scaloni, P.; Conti, M. Monitoraggio del ripascimento protetto con barriera sommersa nella spiaggia di Ostia Centro. Studi Costieri 2004, 8, 3-16.

36. Wilson, D.P. Sabellaria colonies at Duckpool, North Cornwall, 1961-1970. J. Mar. Biol. Assoc. UK 1971, 51, 509-580. [CrossRef]

37. Cunningham, P.N.; Hawkins, S.J.; Jones, H.D.; Burrows, M.T. The Geographical Distribution of Sabellaria alveolata (L.) in England, Wales and Scotland, with Investigations into the Community Structure of, and the Effects of Trampling on Sabellaria alveolata Colonies; Nature Conservancy Council, CSD Report, No. 535; Department of Zoology, University of Manchester: Manchester, UK, 1984. 